\title{
Kajian Pendekatan Kontemporer pada Galeri Seni Selasar Sunaryo Art Space
}

\author{
Sonia Amalia Dunggio ${ }^{1}$, Adibah Nurul Yunisya ${ }^{1^{*}}$ \\ ${ }^{1}$ Lab Perancangan Arsitektur, Program Studi Arsitektur, Fakultas Arsitektur dan Desain, Universitas Pembangunan Nasional \\ "Veteran" Jawa Timur \\ *Penulis Korespondensi: adibahyunisya.ar@upnjatim.ac.id
}

\begin{abstract}
Abstrak:
Perancangan bangunan galeri ditujukan sebagai wadah kegiatan komunikasi visual seni dari para seniman untuk penikmat seni maupun masyarakat, sebagai kebutuhan apresiasi seni untuk keberlanjutan bidang kesenian. Di sisi lain, bangunan sendiri memiliki peranan pembawa citra terhadap kegiatan yang dinaungi. Sehingga, dalam mewujudkan bangunan yang representatif terkait seni kontemporer, galeri seni yang mewadahi karya-karya seni kontemporer semestinya juga memiliki fasad atau sistem bangunan yang mencitrakan unsur kontemporer pula. Oleh sebab itu, penelitian ini bertujuan mengkaji unsur kontemporer yang ada pada bangunan Galeri Seni Selasar Sunaryo Art Space (SSAS) yang memamerkan karya-karya seni kontemporer. Metode penelitian ini akan mengujikan dan menilai tingkat unsur kontemporer yang terwujudkan pada SSAS dengan mengidentifikasi dan mendeskripsikan variabel pendekatan kontemporer pada bangunan tersebut. Hasil penelitian menunjukkan bahwa variabel-variabel pendekatan arsitektur kontemporer nampak pada sebagian besar bangunan SSAS. Dari kajian yang dilakukan, dapat disimpulkan bahwa bangunan SSAS memiliki citra kontemporer yang dapat merepresentasikan karya-karya seni kontemporer yang tersimpan di dalamnya.
\end{abstract}

Kata Kunci: arsitektur; galeri seni; kontemporer

\section{Latar Belakang}

Bangunan dengan fungsi memfasilitasi kegiatan seni umumnya memiliki tatanan ruang terbuka yang mampu mengakomodasi dinamisasi kegiatan seni yang difasilitasinya. Namun sebaliknya, olahan fasad bangunan seni seperti galeri, museum, dan lain sebagainya cenderung dituntut untuk memiliki identitas yang kuat untuk memberi penanda terkait aktifitas yang diakomodasi dalam bangunan tersebut. Sayangnya kebanyakan gubahan massa atau fasad galeri seni di Indonesia masih belum banyak yang menunjukkan identitas yang kuat terhadap karya yang dipamerkan di dalamnya. Hal ini dapat berdampak terhadap penguatan branding produk yang dipamerkan karena tidak didukung dengan identitas bangunannya.

Minimnya identitas bangunan terhadap karya seni yang dipamerkan juga terjadi pada seni-seni kontemporer yang dianggap tergolong populer dari tahun 2000 di Indonesia (Putri \& Sabana, 2016). Walau demikian, karya-karya seni kontemporer di Bandung masih terakomodasi di galeri-galeri seni setempat, contohnya adalah Selasar Sunaryo Art Space. Selasar Sunaryo Art Space (SSAS) merupakan galeri seni yang ditujukan untuk mewadahi perkembangan seni di Indonesia melalui pameran seni kontemporer, pameran, dan sebagainya ("Selasar Sunaryo Art Space Contemporary Art Space," n.d.). Fungsi spesifik bangunan SSAS diharapkan dapat pula tercermin melalui gubahan massa bangunannya agar kegiatan dalam SSAS dapat teridentifikasi dengan maksimal. Oleh sebab itu penelitian ini akan mengkaji pendekatan kontemporer bangunan SSAS terhadap pendekatan Arsitektur Kontemporer.

Pendekatan kontemporer dinilai sesuai dengan kondisi seni masa kini yang terdiri dari berbagai macam aliran dan jenis. Sehingga, terkait kemajuan teknologi serta globalisasi, arsitektur kontemporer merupakan sebuah solusi dalam perancangan bangunan yang dapat memberi tanggapan sesuai dengan perkembangan zaman (Misbahuddin, Haris, \& Widyawati, 2018). Sejauh ini, penelitian pada SSAS yang mengarah pada unsur kontemporer belum pernah dilakukan. Penelitian mengenai SSAS yang ada saat ini terbatas pada kajian ragam akulturasi arsitektur sunda dan modern, sehingga penelitian ini akan memperkaya khasanah penelitian arsitektural melalui kajian pendekatan kontemporer obyek Selasar Sunaryo Art Space.

Maka dari itu, kajian yang dilakukan terhadap Galeri Selasar Sunaryo Art diharapkan mampu memenuhi kriteria unsur kontemporer yang akan dibahas pada penelitian ini. Sehingga dapat memperkaya ilmu pengetahuan, dan menjadikan penelitian ini bermanfaat kedepannya sebagai solusi permasalahan yang relevan dengan kondisi masa kini terutama pada bangunan galeri.

\section{Metode}

Metode yang diterapkan menggunakan analisa deskriptif yang akan dilaksanakan dengan melakukan uraian hasil pengamatan beberapa subjek perancangan yang menerapkan pendekatan kontemporer pada bangunan Selasar Sunaryo Art Space. SSAS berlokasi di area seluas 5.000 meter $^{2}$ pada Jl. Bukit Pakar Timur, Dago, Bandung. 
Bangunan ini memiliki beberapa gubahan massa, namun pada penelitian in subjek perancangan yang akan dikaji adalah bangunan Galeri Ruang A, Galeri Ruang B, Wing Space, Stone Garden, Bamboo House, Amphiteather, Cinderamata Selasar, dan Kopi Selasar. Sehingga penelitian ini akan mengkaji 8 subjek perancangan dari 11 bangunan Selasar Sunaryo Art Space.

\subsection{Metode Pengumpulan Data}

Pengamatan akan dilakukan melalui digital imaging dan street view Google Maps dari tahun 2016 hingga 2021. Penelitian mengkaji bangunan tunggal SSAS dan bangunan kawasan sekitar SSAS sebagai perbandingan galeri seni yang ada di sekitar kota Bandung dalam menentukan Sunaryo Art Space sebagai studi kasus. Penelitian ini akan dimulai dengan pengumpulan data pustaka yang didapat melalui studi jurnal, buku maupun sumber-sumber tertulis mengenai studi kasus perancangan dengan pendekatan arsitektur kontemporer.

\subsection{Metode Analisis Data}

Kajian pustaka yang didapat akan dijadikan dasar kajian dan pembahasan terkait pendekatan kontemporer. Pendekatan kontemporer yang dikaji akan mengidentifikasi tujuh pola karakteristik bangunan kontemporer yang diterapkan oleh Schirmbeck (1987). Tujuh pola karakteristik bangunan kontemporer adalah penggunaan material, penerapan teknologi baru, gubahan yang ekspresif dan dinamis, konsep ruang dengan kesan terbuka, harmonisasi ruang dalam dan ruang luar, kenyamanan hakiki, dan eksplorasi elemen lanskap.

\section{Hasil dan Pembahasan}

Subjek bangunan Selasar Sunaryo dikategorikan mampu membentuk ciri khas yang dapat menggambarkan dan mewakili kondisi seniman maupun masyarakat yang relatable di masa kini. Hal ini sesuai dengan konteks arsitektur yang selalu berkiblat pada keadaan masa kini atau biasa kita sebut sebagai kontemporer. Kata kontemporer sendiri merupakan serapan dari bahasa Inggris, yaitu contemporary yang dapat didefinisikan sebagai sebuah karakter yang sesuai dengan keadaan pada masa kini atau yang sedang terjadi ("Contemporary | Definition of Contemporary by Merriam-Webster," n.d.).

Cikal bakal arsitektur kontemporer diawali dari metode perancangan double coded (Jencks, 2002) yang merupakan sebuah metode perancang dengan titik berat pada beberapa faktor terbentuknya sebuah rancangan di periode tertentu. Dari teori ini berkembang definisi arsitektur kontemporer sebagai gaya arsitektur yang muncul dr segi kemajuan teknologi dan kebebasan berekspresi dan tercipta dari pemisahan keadaan nyata dari komunitas yang bervariasi (Tietz, Hoffman, \& Meuser, 1999). Gagasan ini juga didukung oleh Gunawan, Enjelina, dan Prijadi (2011) yang menyatakan bahwa kontemporer dapat juga diartikan sebagai hal yang "modern atau sesuatu yang up to date" walaupun dalam implementasinya masih dibedakan. Istilah kontemporer umumnya digunakan untuk memaknai karya rancangan yang secara tampilannya, material teknologi dan pengolahan materialnya inovatif, fleksibel, variatif, dan maju. Karena sifatnya yang bebas dan tidak terikat oleh prinsip-prinsip arsitektur konvensional yang baku pada umumnya, maka pendekatan arsitektur dapat ditinjau dengan aspek ciri khas maupun karakter yang terdapat pada bangunan-bangunan arsitektur kontemporer yang terbangun.

Pada proses kajian pendekatan arsitektur kontemporer, tiap aspek yang mempengaruhi ciri khas kontemporer dianalisis hubungan penerapannya melalui fasilitas galeri dan unsur-unsur pembentuk pada galeri Selasar Sunaryo Art Space. Adapun tujuh unsur yang dikaji adalah penggunaan material, penerapan teknologi baru, gubahan yang ekspresif dan dinamis, konsep ruang dengan kesan terbuka, harmonisasi ruang dalam dan ruang luar, kenyamanan hakiki dan eksplorasi terhadap elemen lanskap

\subsection{Penggunaan Material Dan Teknologi Baru: Identifikasi Material}

Pada unsur material, penggunaan material merupakan poin penting dalam perwujudan citra kontemporer. Material yang digunakan tidak perlu semata-mata merupakan material yang paling baru, namun citra kontemporer dapat wula terwujudkan dalam pengaplikasian material tradisional dengan teknologi yang modern. Perpaduan unsur lama dan baru pada penggunaan material yang menjadi indikator utama adanya unsur pendekatan arsitektur kontemporer.

Pada bangunan Selasar Sunaryo perpaduan materi-materi alami dan tradisional sering tampak seperti batu bata dan batu alam. Pada Cinderamata Selasar (Gambar 1) perpaduan dari material batu bata dan dinding yang dikerjakan dengan finishing cat, menjadikan fasad bangunan lebih inovatif. Karena visual selimut bangunan yang setengah jadi dikombinasikan dengan material bata expose memberikan pattern yang unik pada fisik bangunan. Efek kontras yang terjadi antara bangunan dengan lingkungan merupakan indikasi pendekatan pada unsur kontemporer (Gunawan et al., 2011). 


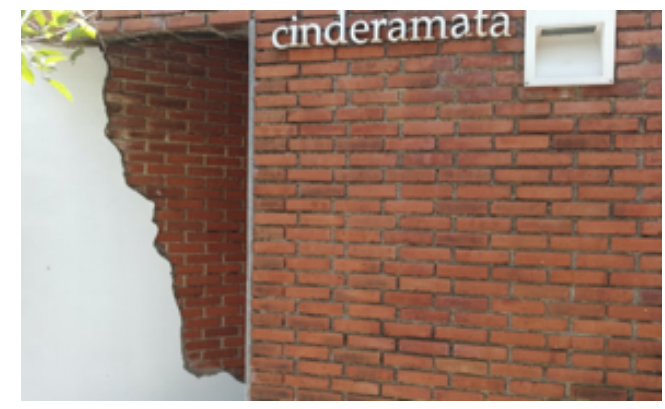

Gambar 1. Efek kontras yang diciptakan pada Cinderamata Selasar.

(Sumber: Egisky, 2020)

Sedangkan pada bangunan Bamboo House material utama yang digunakan adalah bambu, jika dilihat pada (Gambar 2) material bata disekelilingnya berfungsi sebagai jalan berundak dan dinding pembatas menuju area Bamboo House. Perpaduan penerapan material tersebut memberikan visual dengan nuansa tradisional pada bangunan Bamboo House.

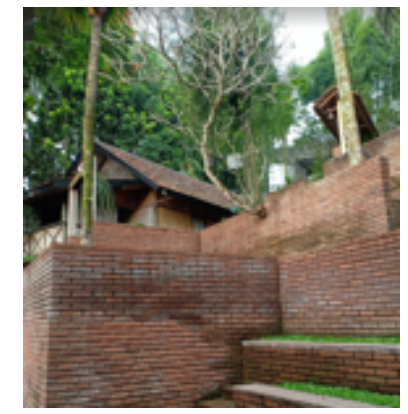

Gambar 2. Bamboo House dengan material bata dan bambu

(Sumber: Bogie, 2021)

Pada area Selasar Sunaryo, dapat dilihat pada (Gambar 3) material-material alami juga kerap ditemukan di ruangruang luar pameran Selasar Sunaryo Art.

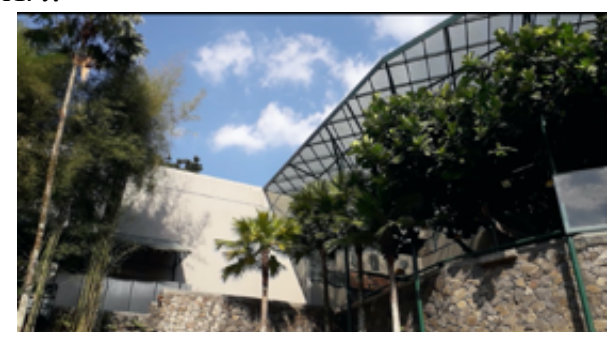

Gambar 3. Ruang Luar Pameran Selasar Sunaryo Art Space

(Sumber: Soneki, 2019)

Selain material alami dan tradisional, material modern seperti kaca juga di aplikasikan pada bangunan galeri Selasar Sunaryo (Gambar 4) sehingga memberikan kesan terbuka atau transparan dimana hal ini mendukung unsur gaya kontemporer yang kekinian (Harmanto, 2018)

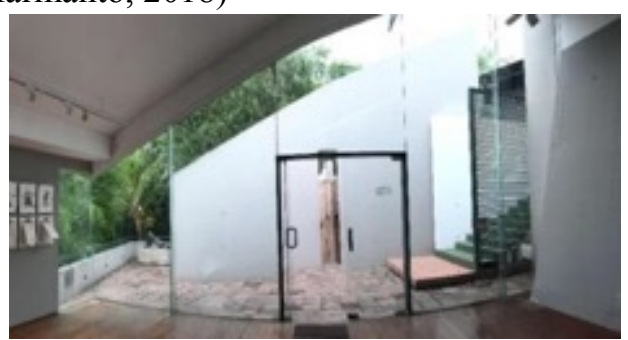

Gambar 4. Galeri A (utama) dengan material kaca

(Sumber: Serena, 2017) 
Pada aspek pengolahan dan penggunaan material, dapat disimpulkan bahwa karakter kontemporer ditunjukkan melalui bangunan Cinderamata Selasar dan bangunan Galeri Utama, hal ini didukung dengan adanya pengolahan antara material alami dan modern. Walaupun begitu unsur kontemporer tidak sepenuhnya ditunjukkan pada bangunan Selasar Sunaryo Art Space, seperti bangunan Bamboo house yang masih mengangkat gaya tradisional Sunda dengan menggunakan konstruksi dari material-material alami. Hal ini berkaitan dengan pernyataan Serena (2017) bahwa bentuk struktur dan konstruksi rumah Sunda menggunakan material utama bambu yang dirakit menjadi bilik atau bidang berpori dengan sambungan ikat atau pasak.

\subsection{Penggunaan Material Dan Teknologi Baru: Identifikasi Animated Architecture}

Penggunaan teknologi pada bangunan kontemporer juga dapat terwujudkan dengan aplikasi teknologi visual yang bersifat animated architecture. Teknologi visual yang dimaksudkan dapat berarti teknologi yang membantu mewujudkan olahan fasad secara animated atau atraktif yang dapat menyesuaikan kebutuhan visual bangunan.

Teknologi yang digunakan Selasar Sunaryo Art Space pada pola animated architecture menggunakan sorotan pencahayaan lampu pada malam hari, khususnya yang terlihat pada bangunan Cinderamata selasar (Gambar 5) yang memberikan kesan dramatis pada bangunan.

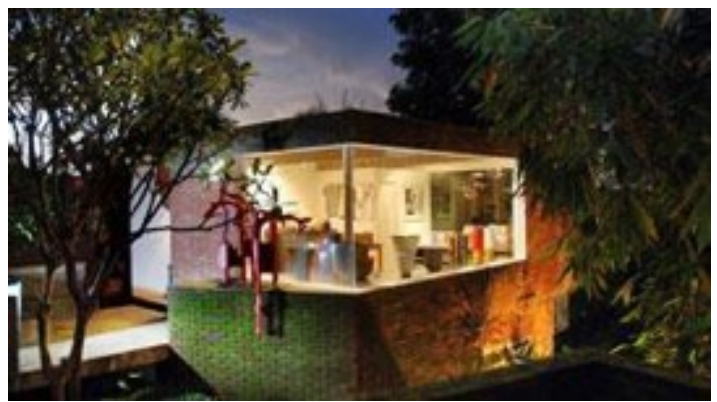

Gambar 5. Cinderamata Selasar Sunaryo Art Space

(Sumber: Shizuka, 2019)

\subsection{Gubahan yang ekspresif dan dinamis: Identifikasi Gubahan}

Gubahan ekspresif dan dinamis pada gubahan dan tampilan menunjukkan adanya penyesuaian tampilan yang berlandaskan perkembangan jaman. Penyesuaian inilah yang menjadi dasar dari unsur arsitektur kontemporer. Menurut official website Selasar Sunaryo Art Space menyatakan "The basic form of the buildings was inspired by the shape of 'kuda lumping', a traditional Indonesian cultural artifact." Pola peletakan gubahan massa bangunan terinspirasi dari bentuk kebudayaan tradisional Jawa yaitu Kuda Lumping yang ditransformasikan. Gubahan massa yang disusun tidak terikat pada garis pola luar tapak. Penataan pola massa juga cukup ekspresif terlihat dari penyusunannya yang tersebar dan mengisi ruang-ruang pada tapak (Gambar 6). Sedangkan unsur dinamis pada pengolahan komposisi bangunan Selasar Sunaryo dalam tapak hanya terlihat pada area amphiteather yang berada di tengah tapak.

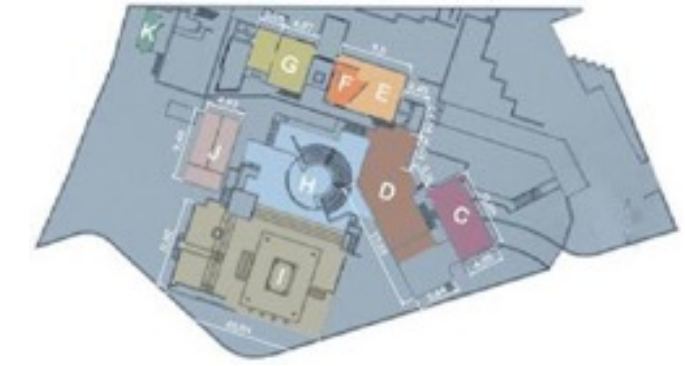

Keterangan

C: Wing Space E: Central Space

D: Kopi Selasar F: Cinderamata

\begin{abstract}
G: Audio Visual Spac H: Amphitheatre
\end{abstract}

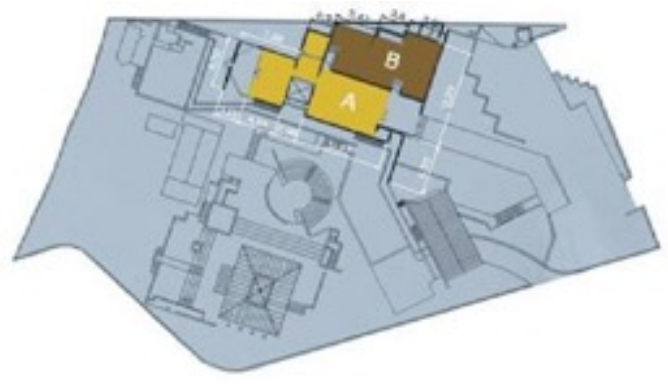

Keterangan

A: Stone Garden

B: Main Space

Gambar 6. Siteplan Selasar Sunaryo Art Space

(Sumber: Iskandar, Astrin Athina, \& Arfina Deviliani, 2013) 


\subsection{Gubahan yang ekspresif dan dinamis: Identifikasi Bentuk dan Tampilan}

Selasar Sunaryo Art Space menyuguhkan bentuk dan tampilan bangunan yang relevan dengan masa kini, yaitu gaya modern. Namun style modern disajikan dengan lebih atraktif melalui fasad bangunan. Selaras dengan galeri utama Sunaryo Art Space, bentuk trapesium pada massa galeri utama diolah dengan penambahan dan pengurangan gubahan massa untuk mendapatkan hasil yang sedemikian rupa, sehingga kesan berbeda (anti- mainstream) didapatkan pada desain galeri. Menurut Gunawan et al (2011)penggunaan bentuk-bentuk bersifat trapezoid, zigzag, geometri, dan bentuk puzzle, yang banyak terlihat pada karya mula-mula dalam art deco dapat diaplikasikan pada rancangan arsitektur kontemporer. Sehingga, penggunaan bentuk trapesium pada gedung galeri utama memunculkan unsur kontemporer arsitekturnya (Gambar 7).

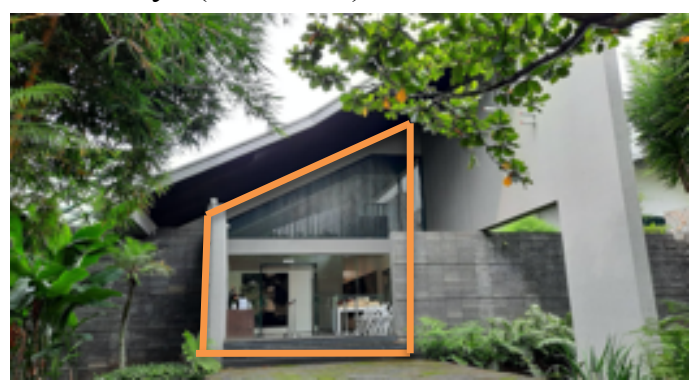

Gambar 7. Bentuk Trapesium pada Galeri utama Sunaryo Art Space

(Sumber: Rangga, 2020)

\subsection{Identifikasi Komposisi Ruang}

Menurut Kusumaningrum, Rahayu, dan Budiarto (2019), prinsip arsitektur kontemporer menerapkan komposisi ruang-ruang yang saling berkaitan serta multifungsi atau berhubungan secara langsung maupun tidak langsung melalui bukaan-bukaan yang terletak pada bangunan, seperti void, jendela, atau pintu. Pada subjek rancangan Selasar Sunaryo Art Space bentuk ruang pada galeri (Gambar 8) mengikuti gubahan massa galeri, yaitu ruang dengan bentuk trapesium. Sehingga langit-langit ruang yang tampak pada bagian interior berbentuk miring. Hal ini memberikan kesan ke pengunjung untuk merasakan komposisi ruang yang mengarahkan atau menuntun pengunjung mengikuti arahan bentuk bangunan ke skala ruang yang lebih kecil (peralihan ruang).

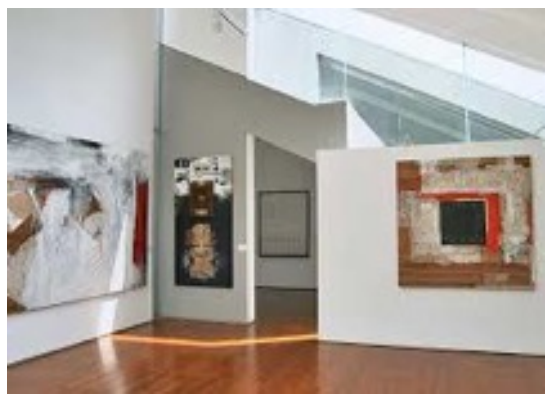

Gambar 8. Ruang dalam galeri utama

(Sumber: Ryan, 2017)

Permainan komposisi ruang juga diterapkan pada interior bangunan yang berkaitan dengan display pada ruangruang dalam galeri, komposisi ruang terbagi berdasarkan penataan display (Gambar 9), ruang ini diciptakan dengan tujuan menarik pengunjung untuk berinteraksi lebih dekat dengan karya seni kontemporer yang ditampilkan.
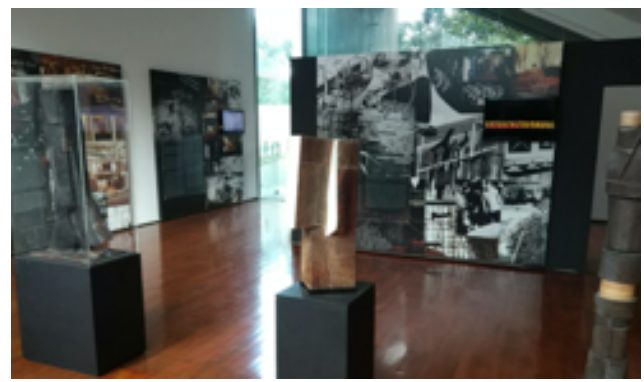

Gambar 9. Ruang dalam galeri Selasar Sunaryo

(Sumber: Eric, 2017) 


\subsection{Konsep Ruang dengan Kesan Terbuka}

Febrianti, Yuliarso, dan Pramesti (2018), menerjemahkan konsep ruang dengan kesan terbuka pada karakter kontemporer dengan definisi penggunaan dinding dari kaca, antara ruang dan koridor dalam bangunan serta bukaan yang optimal sehingga memberikan kesan bangunan terbuka dan tidak massif pada pola peruangannya. Hal ini dapat ditemukan pada tampilan massa galeri utama (Gambar 10), komposisi transparan mendominasi pada bagian fasad. Material kaca digunakan pada selimut bangunan untuk menambahkan kesan ruang terbuka.

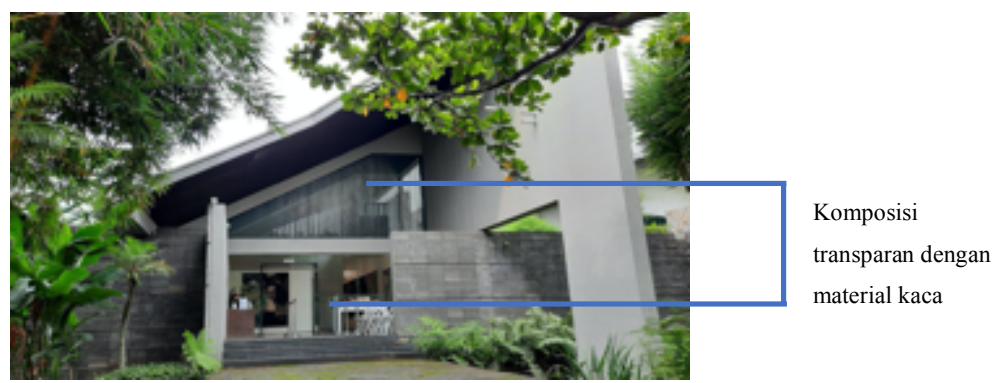

Gambar 10. Komposisi Transparan pada Fasad Galeri utama Sunaryo Art Space

(Sumber: Rangga, 2020)

Penggunaan material kaca tetap menjaga privasi pengguna pada ruang dalam, walaupun memiliki kesan terbuka pemilihan komposisi kaca disesuaikan dengan kebutuhan dan ruang (Gambar 11).

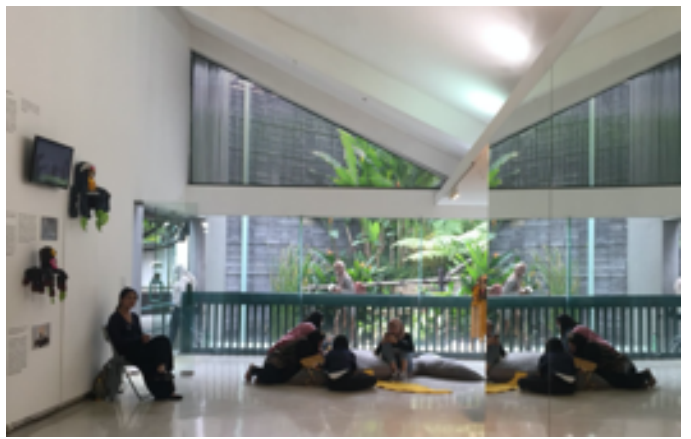

Gambar 11. Komposisi Transparan pada Interior Galeri Sunaryo Art Space

(Sumber: Widya, 2018)

Selain itu galeri Sunaryo Art Space juga mengusung tema open space (gambar 12) yang memanfaatkan ruangruang di lahan terbuka sehingga suasana yang didapatkan menyatu dengan lingkungan sekitar, hal ini menambah nilai karakteristik gaya kontemporer pada galeri Sunaryo Art Space.

\subsection{Harmonisasi Ruang Dalam dan Ruang Luar}

Harmonisasi ruang dalam dan ruang luar dapat dilakukan melalui pembedaan pola lantai atau bahan lantai (Febrianti et al., 2018). Pada Selasar Sunaryo pola lantai yang kontras ditunjukkan melalui penataan massa pada ketinggian yang berbeda-beda, hal ini dikarenakan kondisi tapak yang berkontur di area perbukitan.

Arsitektur kontemporer identik dengan konsep ruang yang terkesan terbuka atau open plan, harmonisasi ruangan yang menyatu dengan ruang luar, memiliki fasad yang terbuka (Misbahuddin et al., 2018). Hal ini berlaku pada Selasar Sunaryo Art Space yang mengusung tema Open Space galeri, sesuai dengan judulnya yang berarti selasar atau beranda. Selasar Sunaryo Art Space menekankan ruang-ruang terbuka yang membuat pengunjung menikmati kesejukan di lingkungan perbukitan, ruang dirancang terbuka untuk menstimulus kegiatan berjejaring dan interaksi antar pengguna. Seperti pada Amphitheatre outdoor difungsikan untuk menikmati pertunjukkan karya seni, terdapat juga café outdoor dimana pengunjung dapat menikmati pemandangan Dago Hills melalui bangunan café yang berada di ketinggian.

Harmonisasi juga ditunjukkan pada pemilihan lokasi Amphiteathre yang memanfaatkan perbedaan level ketinggian tanah. Hal ini ditunjukkan dari adanya integrasi antara alam dengan rancangan karena peletakan rancangan sesuai dengan konteks. Suasana alami juga terbentuk dari baiknya posisi level bawah dan atap yang terbuka. Sehingga konsep menyatu dengan alam terbentuk dengan maksimal (Hartabela, 2016). 


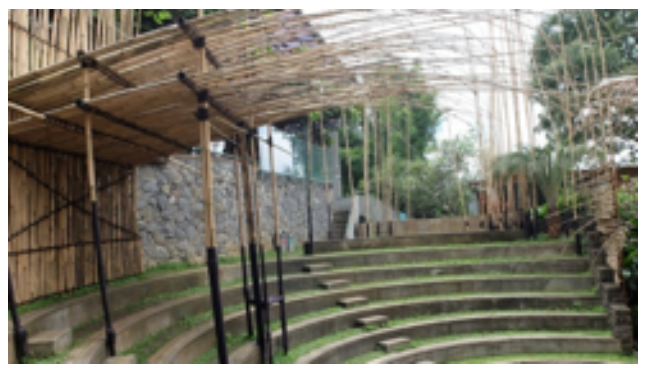

Gambar 12. Amphitheater Selasar Sunaryo Art Space

(Sumber: Baban, 2016)

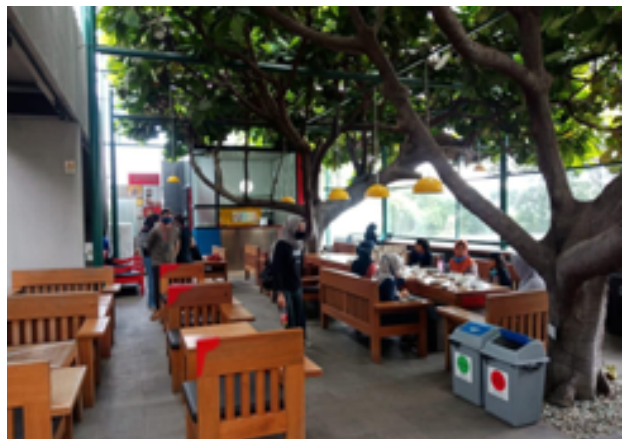

Gambar 13. Cafe shop Selasar Sunaryo Art Space

(Sumber: Putu Intan, 2020)

\subsection{Kenyamanan Hakiki}

Arsitektur kontemporer merupakan penggunaan warna sesuai kebutuhan, penggunaan material dan tekstur berdasarkan kegunaan ruang, pencahayaan dan penghawaan yang baik dan tidak mengganggu (Febrianti et al., 2018). Penerapan pencahayaan alami pada interior Selasar Sunaryo berperan sebagai pembatas ruang. Pencahayaan alami yang diberikan di setiap ruang galeri menambahkan citra melankolis di setiap ujung ruang galeri dengan tone cahaya cold. Aplikasi material modern berupa kaca diposisikan pada celah-celah tinggi bangunan hingga plafon, sehingga pencahayaan dapat diteruskan ke dalam ruangan (Gambar 13). Hal ini sesuai dengan pendapat Schirmbeck (1987), selain sebagai unsur desain yang inovatif memasukan cahaya ke dalam ruangan merupakan salah satu penerapan pendekatan arsitektur kontemporer dalam desain.

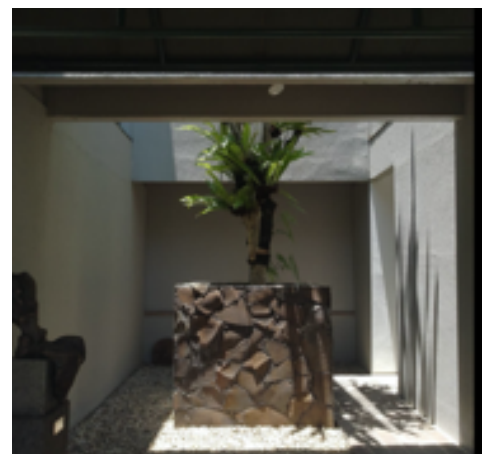

Gambar 13. Ruang dalam Galeri Utama Selasar Sunaryo Art Space

(Sumber: Fariz, 2018)

Kualitas dan suasana ruang tercipta melalui penggunaan warna yang sesuai dengan kebutuhan, pemilihan material, juga tekstur berdasarkan fungsi ruang (Febrianti et al., 2018). Desain yang dibentuk pada ruang-ruang galeri terkesan bersifat informal dengan perpaduan dinding gypsum dan bata yang di cat putih merepresentasikan ruang sederhana yang netral (Gambar 14). Sehingga tidak menganggu fokus kenyamanan pengunjung dalam menikmati karya seni. Ruang informal juga berfungsi menstimulus visual pergerakan pengunjung dan meminimalisir kebosanan pengunjung dalam menikmati karya seni. 


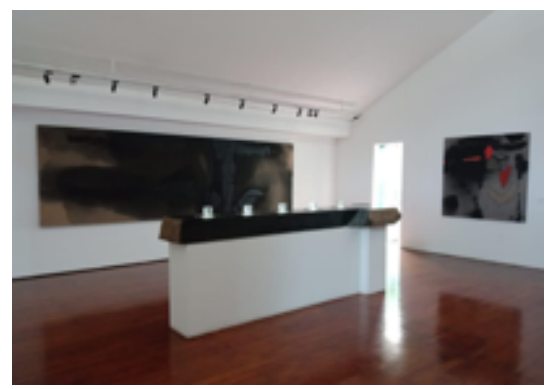

Gambar 14. Interior Wing Space Galeri Sunaryo Art Space

(Sumber: Putu Intan, 2020)

Warna-warna yang bersih dan tegas disajikan pada eksterior selimut bangunan, yakni putih (Gambar 15). Hal ini termasuk aspek yang membentuk ciri arsitektur kontemporer.

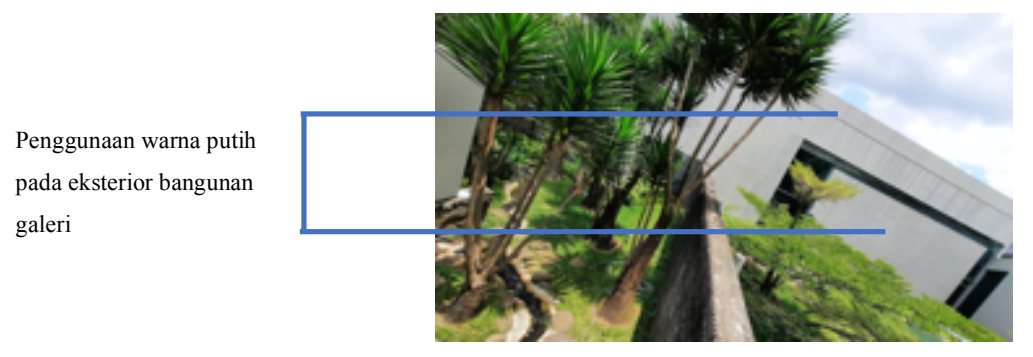

Gambar 15. Warna Galeri Sunaryo Art Space

(Sumber: Paulus, 2020)

\subsection{Eksplorasi Elemen Lanskap}

Tingkatan eksplorasi elemen lansekap pada bangunan menjadi indikator bagaimana unsur kontemporer juga diwujudkan di lingkungan bangunan sebagai bagian dari suatu sistem arsitektur yang terpadu. Menurut Serena (2017), pada Selasar Sunaryo terdapat 3 karakteristik utama yang terdapat pada lansekap kampung adat Sunda, yaitu elemen air, elemen hutan keramat, dan kontur tanah yang berundak.
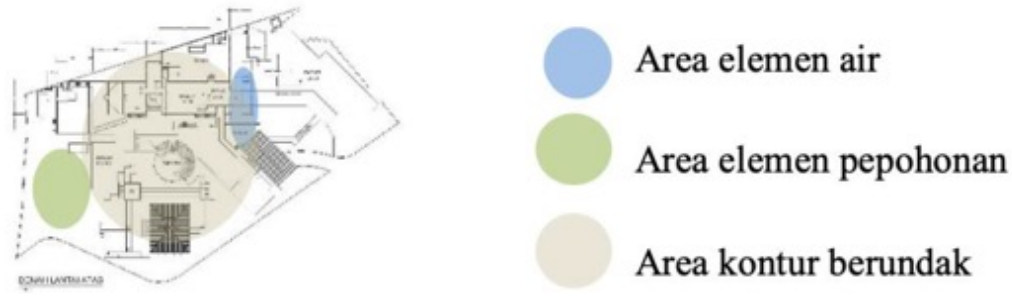

Gambar 16. Elemen Lanskap Selasar Sunaryo Art Space

(Sumber: Serena, 2017)

Namun pengolahan tersebut dilakukan dengan gaya baru tanpa mengusung fungsi atau makna tatanan lansekap Sunda. Pada Selasar Sunaryo juga terdapat material lunak dan keras yang diolah secara modern. Material lunak berupa rumput gajah dan juga tanaman rindang (Gambar 17).

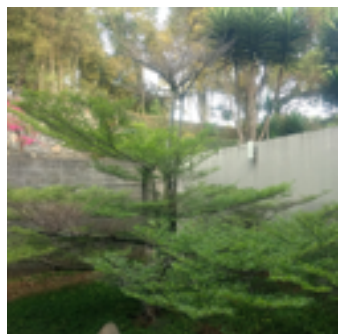

Gambar 17. Penataan Lanskap di area Outdoor Galeri Sunaryo Art Space

(Sumber: Tian, 2021) 


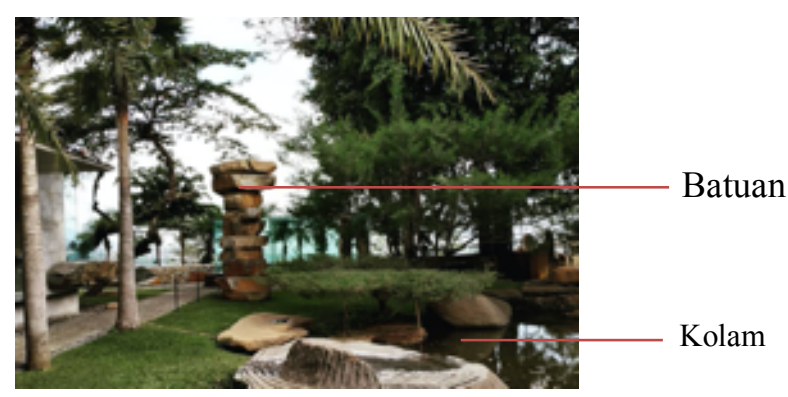

Gambar 18. Hard Material pada lanskap Selasar Sunaryo Art Space

(Sumber: Jay, 2020)

Selain material lunak terdapat juga material berupa hiasan taman berupa batuan yang ditumpuk sebagai dekorasi taman dan kolam disampingnya (Gambar 18 \& 19) pada lanskap Selasar Sunaryo Art Space.

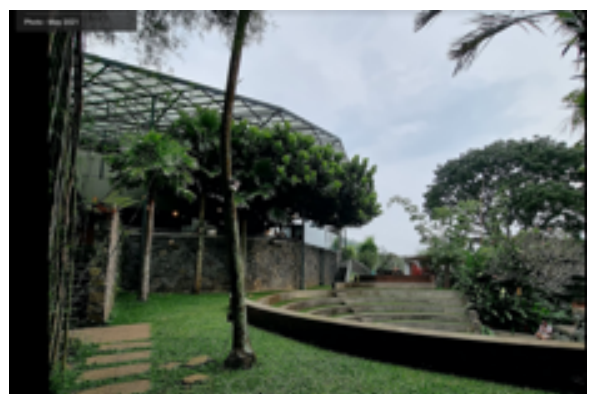

Gambar 19. Pengolahan lanskap pada Amphiteather Selasar Sunaryo Art Space

(Sumber: Baban, 2016)

Melalui kajian lanskap dapat disimpulkan bahwa terdapat unsur Sunda yang diadopsi pada Selasar Sunaryo Art Space namun diolah dengan gaya baru yang relatable dengan gaya kontemporer masa kini. Sesuai dengan pendapat Sumalyo (2005), kontemporer adalah bentuk-bentuk aliran arsitektur yang tidak dapat dikelompokkan dalam suatu aliran arsitektur atau sebaliknya berbagai arsitektur tercakup di dalamnya. Sehingga dapat disimpulkan area lanskap Selasar merupakan perpaduan antara unsur Sunda dan modern yang menciptakan karakter atau ciri khas arsitektur kontemporer.

\section{Kesimpulan}

Hasil penelitian membuktikan bahwa penerapan pendekatan kontemporer dapat di analisa melalui pola karakteristik dan ciri arsitektur kontemporer yang erat melekat dan menjadi identitas yang berbeda pada bangunanbangunan berkonsep arsitektur kontemporer. Terdapat 6 pola karakter menurut Schirmbeck (1987) yang dirangkum dan dianalisa terhadap objek Selasar Sunaryo Art Space.

Tabel 1. Perwujudan Pendekatan Arsitektur Kontemporer pada Selasar Sunaryo Art Space

\begin{tabular}{lll}
\hline No & Unsur Arsitektur Kontemporer & Perwujudan Arsitektur Kontemporer pada SSAS \\
\hline 1 & $\begin{array}{l}\text { Penggunaan Material Dan Teknologi } \\
\text { Baru: Identifikasi Material }\end{array}$ & Olahan material tradisional dengan teknik pembangunan modern \\
\hline 2 & $\begin{array}{l}\text { Penggunaan Material Dan Teknologi } \\
\text { Baru: Identifikasi Animated Architecture }\end{array}$ & $\begin{array}{l}\text { Penggunaan lampu sorot pada titik-titik strategis yang mewujudkan } \\
\text { tampilan dramatis }\end{array}$ \\
\hline 3 & $\begin{array}{l}\text { Gubahan yang ekspresif dan dinamis: } \\
\text { Identifikasi Gubahan }\end{array}$ & Gubahan merupakan perwujudan dinamis dari bentuk kuda lumping \\
\hline 4 & $\begin{array}{l}\text { Gubahan yang ekspresif dan dinamis: } \\
\text { Identifikasi Bentuk dan Tampilan }\end{array}$ & $\begin{array}{l}\text { Adanya gubahan yang berbentuk dinamis dengan hubungan ruang dalam } \\
\text { yang modern }\end{array}$ \\
\hline 5 & Identifikasi Komposisi Ruang & Adanya ruang yang bersifat multi fungsi \\
\hline 6 & Konsep Ruang dengan Kesan Terbuka & $\begin{array}{l}\text { Adanya bukaan kaca yang lebar dan cukup mendominasi olahan dinding } \\
\text { SSAS }\end{array}$ \\
\hline 7 & Harmonisasi Ruang Dalam dan Ruang & Tatanan ruang dalam dengan model denah open plan \\
\hline 8 & Luar & Adanya kombinasi kenyamanan yang diwujudkan dengan pencahayaan \\
& & yang tidak mencolok dan sirkulasi udara yang nyaman \\
\hline 9 & Eksplorasi Elemen Lanskap & Tatanan taman yang modern dengan objek taman yang kontemporer \\
\hline
\end{tabular}


Berdasarkan hasil identifikasi didapatkan hasil kesimpulan bahwa identifikasi penggunaan material didominasi dengan material alami (Tabel 1), tradisional yang diekspos yaitu batu-bata dan material modern berupa kaca yang dipadukan dengan teknologi baru menggunakan metode animated architecture. Identifikasi gubahan yang ekspresif digambarkan melalui tatanan massa yang berupa hasil transformasi bentuk "Kuda Lumping" yang ditata secara ekspresif dan mengisi ruang tidak terikat oleh pola garis tapak. Sedangkan unsur gubahan dinamis terdapat hanya pada Amphitheathre yang berlokasi di area tengah tapak. Identifikasi konsep ruang dengan kesan terbuka identik bermain dengan komposisi transparan dan efek penambahan cahaya alami melalui celah-celah tinggi pada ujung ruang galeri. Identifikasi harmonisasi ruang dalam dan ruang luar yang disajikan melalui tema Open Space juga menggunakan metode pembeda ketinggian sebagai symbol pemisah antar ruang luar dan ruang dalam. Identifikasi kenyamanan hakiki yang didapatkan dari elemen-elemen pembentuk ruang seperti suasana ruang, warna, tekstur dan material ruang yang sederhana namun tetap menarik dan tidak monoton. Identifikasi eksplorasi elemen lanskap dengan mengadopsi unsur sunda yang diolah dengan penataan lanskap yang modern, menjadikan ciri khas kontemporer makin terlihat.

Sehingga berdasarkan hasil identifikasi bentuk dan tampilan didominasi menggunakan unsur pendekatan kontemporer jika dibandingkan dengan unsur Sunda yang terdapat pada Selasar Sunaryo Art Space. Pola yang terlibat pada Selasar Sunaryo Art Space sarat dengan unsur pembentuk karakter arsitektur kontemporer. Pada penerapan pendekatan kontemporer dibutuhkan karakter atau citra yang dapat dibentuk oleh suatu perancangan bangunan. Karena karakter arsitektur kontemporer yang jangkauannya bebas dan luas maka membutuhkan tingkat kreativitas dan karakter arsitek yang kuat dalam menciptakan desain-desain inovatif yang disesuaikan dengan kebutuhan desain bangunan di masa kini.

\section{Daftar Pustaka}

Contemporary | Definition of Contemporary by Merriam-Webster. (n.d.). Retrieved May 4, 2021, from https://www.merriam-webster.com/dictionary/contemporary

Febrianti, I. N., Yuliarso, H., \& Pramesti, L. (2018). PENERAPAN ARSITEKTUR KONTEMPORER DALAM PERANCANGAN PUSAT JASA PERNIKAHAN DI BEKASI. In SENTHONG. Retrieved from https://jurnal.ft.uns.ac.id/index.php/senthong/article/view/662

Gunawan, D., Enjelina, K., \& Prijadi, R. (2011). REAKTUALISASI RAGAM ART DECO DALAM ARSITEKTUR KONTEMPORER. In MEDIA MATRASAIN (Vol. 8). Retrieved from https://ejournal.unsrat.ac.id/index.php/jmm/article/view/315

Harmanto, M. (2018). LANDASAN TEORI DAN PROGRAM HOTEL BINTANG 4 DI KOTA MAGELANG.

Hartabela, D. (2016). Penerapan Teori Topografi pada Lanskap Arsitektur Selasar Sunaryo. In TEMU ILMIAH IPLBI 2016.

Iskandar, I., Astrin Athina, N., \& Arfina Deviliani, R. (2013). Fleksibilitas Sistem Elemen Interior Pada Selasar Sunaryo Art Space. In Jurnal Online Institut Teknologi Nasional Januari (Vol. 01). Retrieved from http://fariable.blogspot.com

Jencks, C. (2002). The new paradigm in architecture: the language of post-modernism. Yale University Press.

Kusumaningrum, K., Rahayu, R. L., \& Budiarto, A. (2019). PENDEKATAN ARSITEKTUR KONTEMPORER PADA SEKOLAH TINGGI BISNIS BUSANA DI TRANSISI RUANG URBAN-KELAPA GADING JAKARTA UTARA. Seminar Nasional Komunitas Dan Kota Berkelanjutan, 1(1), 51-57. Retrieved from http://www.proceeding.unindra.ac.id/index.php/semnaskkbarsi/article/view/3888

Misbahuddin, Haris, S., \& Widyawati, K. (2018). PERANCANGAN WORKSHOP DAN GALERI SENI RUPA DENGAN PENDEKATAN ARSITEKTUR KONTEMPORER DI JAKARTA SELATAN. 01(01), 57-64.

Putri, K. R. S., \& Sabana, S. (2016). Re-Interpretasi Budaya Tradisi dalam Karya Seni Kontemporer Bandung Karya Radi Arwinda. Panggung, 26(3). https://doi.org/10.26742/panggung.v26i3.193

Schirmbeck, E. (1987). Idea, Form, and Architecture: Design Principles in Contemporary Architecture. Van Nostrand Reinhold Company.

Selasar Sunaryo Art Space - Contemporary Art Space. (n.d.). Retrieved May 4, 2021, from http://www.selasarsunaryo.com/

Serena, G. (2017). Ragam akulturasi arsitektur Sunda dan modern pada Selasar Sunaryo Art Space.

Sumalyo, Y. (2005). Arsitektur Modern: Akhir Abad XIX dan Abad XX. Edisi ke 2. Gadjah Mada University Press.

Tietz, J., Hoffman, W., \& Meuser, P. (1999). The story of architecture of the 20th century. Konemann. 